\title{
Effect of Magnesia Investments in the Dental Casting of Pure Titanium or Titanium Alloys
}

\author{
Kazuo IDA, Toshihiro TOGAYA, Sadami TSUTSUMI and Masatoshi TAKEUCHI \\ Department of Dental Materials, Research Center for Medical Polymers and Biomaterials, Kyoto University \\ Sakyo-ku, Kyoto, Japan
}

Received on September 23, 1982

Pure titanium and titanium-based alloys were cast into molds of phosphate-bonded silica or magnesia investments using a new casting machine known as the "CASTMATIC". The properties of the castings were much better using magnesia, rather than phosphate-bonded silica, investments.

Key Words: Dental Casting, Titanium, Magnesia Investment

\section{INTRODUCTION}

For past several years, precious alloys have been gradually replaced by non-precious ones in the dental casting field because of the rising price of dental alloys. In Japan during the past ten years, nickel-chromium alloys have been used extensively for crown or bridge and porcelain-fused-to-metal restorations instead of gold or silver alloys. This tendency seems to be the same all over the world. However, the expanded use of nickel-containing base metal alloys in dentistry has raised questions concerning their biological safety, namely, carcinogenic and sensitivity risks. ${ }^{1)}$

On the other hand, since pure titanium or titanium-based alloys have excellent biocompatibility, they have been applied as dental implants and bone screws or artificial joints in the orthopedic field. Titanium is considered to have following advantages over conventional dental casting alloys: (1) the specific gravity of titanium is about a half of nickel- or cobalt-based alloys, (2) the corrosion or tarnish resistance of titanium is excellent, (3) the mechanical properties of pure titanium are nearly equal to those of dental gold alloys, (4) although the price of titanium is about the same or a little higher than that of cobalt or nickel at the present, titanium has the potentiality of becoming the most inexpensive metal when considering its specific gravity.

However, titanium has a serious weak point, namely, its high melting temperature and chemical reactivity at high temperatures. In other words, titanium is so easily oxidized and reacts with the ceramic crucible during melting that it is difficult to cast pure titanium or titanium alloys in the conventional dental casting mold.

So far, there have been some papers about dental casting of titanium-based alloys or pure titanium. For example, it was reported that a $82 \% \mathrm{Ti}-13 \% \mathrm{Cu}-5 \% \mathrm{Ni}$ alloy was melted and cast at about $1500^{\circ} \mathrm{C}$ using conventional equipment and a commercial phosphatebonded investment. ${ }^{2)}$ Probably this could be performed because of the lowered melting temperature resulting from alloying the titanium with copper and nickel. We have presented several papers in this field in a Japanese journal ${ }^{3 \sim 7)}$ and IADR meetings ${ }^{8,9)}$ since 1980.

There are two ways to cast pure titanium or titanium-based alloys. One is to utilize 
the conventional dental casting technique by alloying and thus lowering the melting temperature of titanium, and the other is to use a super high temperature resistant mold material and a new casting machine suitable for the casting of titanium.

The purpose of this communication is to show the feasibility of using pure titanium or titanium alloys for dental casting employing a newly developed casting machine, the "CASTMATIC".

\section{MATERIALS AND METHODS}

(1) Structure and operation of the "CASTMATIC"

The external view and internal structure of the dental casting machine, "CASTMATIC", are shown in Figure 1 (a) and (b). As seen in (b), this machine consists of an upper melting chamber and a lower casting chamber, both of which are connected by a central hole with each other. A casting ring is set at the bottom of the hole, and a crucible made of copper or graphite lies on top of it. A piece of alloy is placed in the center of the crucible.

Several casting steps proceed automatically by pushing the "start" button. At first both the upper and lower chambers are evacuated by a built-in vacuum pump. After the air is exhausted, compressed argon gas is fed into the upper chamber and an arc is soon generated between a tungsten electrode $(-)$ and the alloy $(+)$. Since the lower chamber has been kept under vacuum all the time, a flow of argon is maintained in the casting ring due to the pressure difference between the upper and lower chambers.

Immediately after the alloy has melted completely in the inert atmosphere, the molten

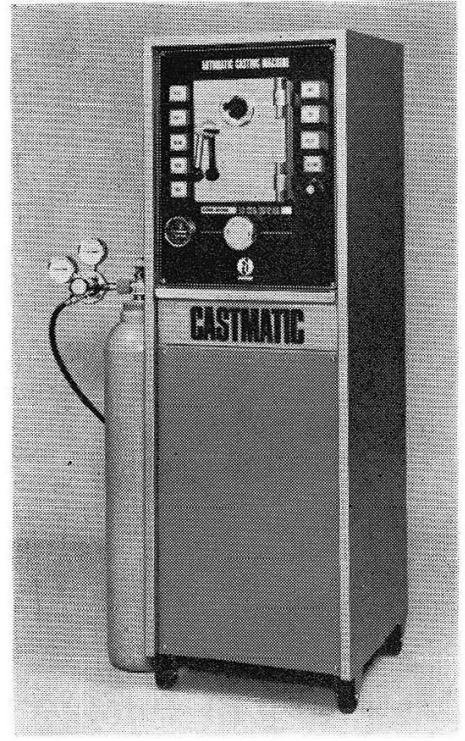

(a) External view of "CASTMATIC"

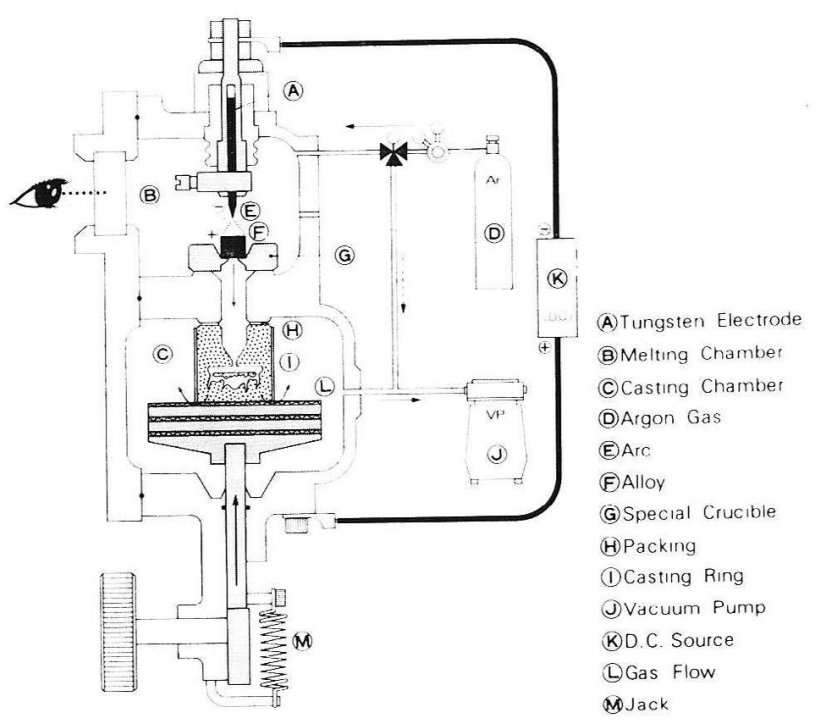

(b) Schematic diagram of principal parts of the machine

Figure 1 Structure of "CASTMATIC"

* Manufacturer: IWATANI and CO., LTD., Osaka, Japan 
metal naturally falls down through the central hole and runs into the mold in the ring.

In the "CASTMATIC", the crucible is made of copper or graphite instead of ceramics, so that titanium or titanium alloys do not react with the crucible. This machine makes the casting of titanium possible because of its high temperature heating source, highly inert atmosphere, and highly durable crucible.

(2) Materials

The pure titanium and titanium-based alloys shown in Table 1 were tested. Pure titanium and the $6 \mathrm{Al}-4 \mathrm{~V}-\mathrm{Ti}$ alloy were Japanese commercial products. The $13 \mathrm{Cu}-\mathrm{Ti}$ alloy was made in USA. Ti-based binary or ternary alloys were made in the "CASTMATIC" by placing each component of the alloys together in a crucible without a hole, melting them with an argon arc, and shaping the alloys into small ingots in the crucible.

As mold materials, commercial phosphate-bonded investments and refractory industrial magnesia cement were used as shown in Table 2.

(3) Methods

A part of the magnesia cement was pulverized into fine powder by a ball mill for 12 hours to use it as a coating material. The particle size distribution of the mold materials was measured by a laboratory sieve shaker, "ANALYSETTE 3"*.

For measuring the compressive strength and thermal expansion of mold materials, cylindrical specimens were shaped in the metal mold. In the case of magnesia cement, unpulverized coarse powder was used for this test. The dimensions of specimens were

Table 1 Metals and alloys used

\begin{tabular}{|c|c|c|c|}
\hline No & Types & Brand name or component & Manufacturer \\
\hline 1 & pure titanium & $\mathrm{KS}-50$ & Kobe Steel Ltd. \\
\hline 2 & 6Al-4V-Ti alloy & AMS-2928H & Kobe Steel Ltd. \\
\hline 3 & $13 \mathrm{Cu}-\mathrm{Ti}$ alloy & - & Made in USA* \\
\hline 4 & Ti-based binary alloys & Ti-Al, Ti-Co, Ti-Cr & Made in laboratory \\
\hline 5 & Ti-based ternary alloys & $\begin{array}{l}\text { Ti-Cu, Ti-Fe, Ti-Ni, etc. } \\
\text { Ti-Cu-Ni, etc. }\end{array}$ & Made in laboratory \\
\hline
\end{tabular}

*Manufacturer is unknown, samples were obtained by courtesy of Dr. Waterstrat.

Table 2 Mold materials used

\begin{tabular}{l|c|l}
\hline Investment material & Brand name & \multicolumn{1}{c}{ Manufacturer } \\
\hline Magnesia Cement & M-4* & $\begin{array}{l}\text { Nihon Chemical } \\
\text { Ceramics Co., Ltd. }\end{array}$ \\
\hline $\begin{array}{l}\text { Phosphate-bonded } \\
\text { silica }\end{array}$ & WASHI-Vest & $\begin{array}{l}\text { Kamemizu Chemical } \\
\text { Industry Co., Ltd. }\end{array}$ \\
\hline
\end{tabular}

*Composition of $\mathrm{M}-4, \mathrm{MgO}: 96.0 \%, \mathrm{SiO}_{2}: 1.5 \%, \mathrm{Na}_{2} \mathrm{O}: 0.5 \%$

$\mathrm{Fe}_{2} \mathrm{O}_{3}: 0.5 \%, \mathrm{Al}_{2} \mathrm{O}_{3}: 0.3 \%$

* Manufacturer: PRITSCH GMBH, Laborgerätebau, Germany 
$6.0 \mathrm{~mm} \phi \times 10 \mathrm{mmH}$ and $5.0 \mathrm{~mm} \phi \times 20 \mathrm{mmH}$ for strength and expansion measurements, respectively.

As mechanical properties of the castings, the tensile strength, elongation and hardness were measured. The shape of wax patterns were the rod type $(2.0 \mathrm{~mm} \phi \times 40 \mathrm{mmL})$ and the square plate type $(10 \times 10 \times 2.4 \mathrm{~mm})$ as shown in Figure 2 .

The water/powder ratios of mold materials were 0.24 for phosphate-bonded investments; and for the magnesia cement, they were 0.20 for coating materials and 0.13 for secondary investing materials. The coating of wax patterns was always adopted for magnesia investments; but there were two types of phosphate-bonded investments, namely, those coated with fine powder of magnesia cement and those not coated. Figure 3 shows the wax aptterns after coating.

After drying the coating material, the casting ring was set on the crucible former and the investment was poured into the ring. After setting, the rings were put into the electric furnace. The firing temperature was ordinarily $800^{\circ} \mathrm{C}$ for both phosphate-bonded and magnesia mold materials, but it was changed in accordance with the purpose of experiment. After the molds were kept at their highest temperature for more than 30 minutes, they were taken out of furnace, and the casting was carried out in the above-mentioned "CASTMATIC".

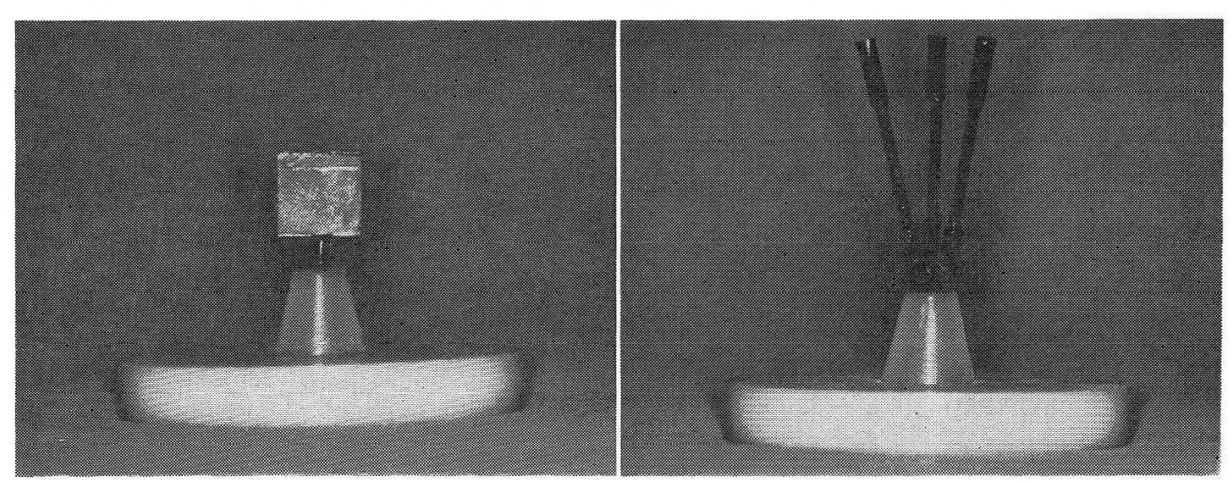

Figure 2 Wax patterns

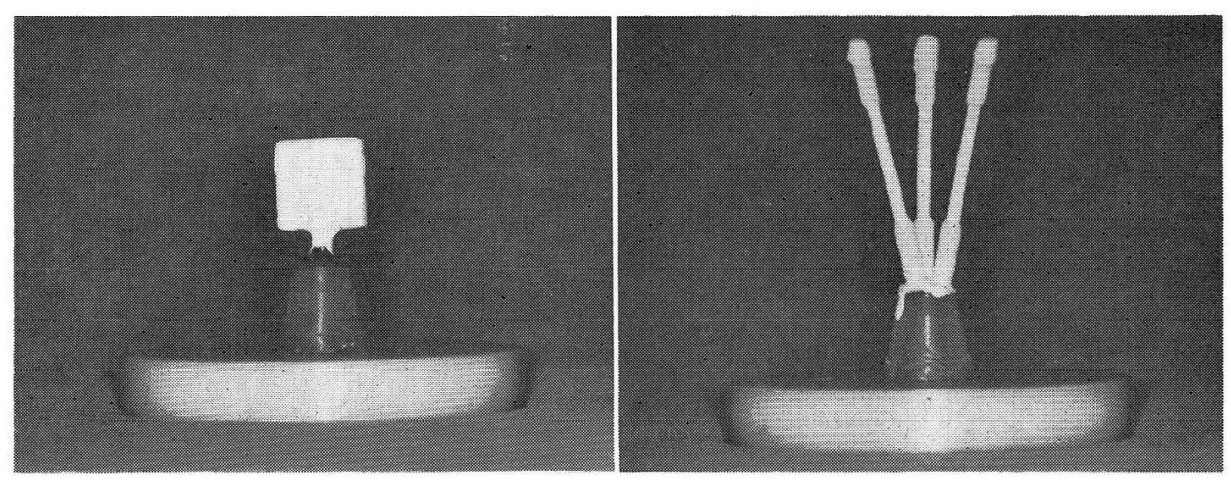

Figure 3 Wax patterns after coating 


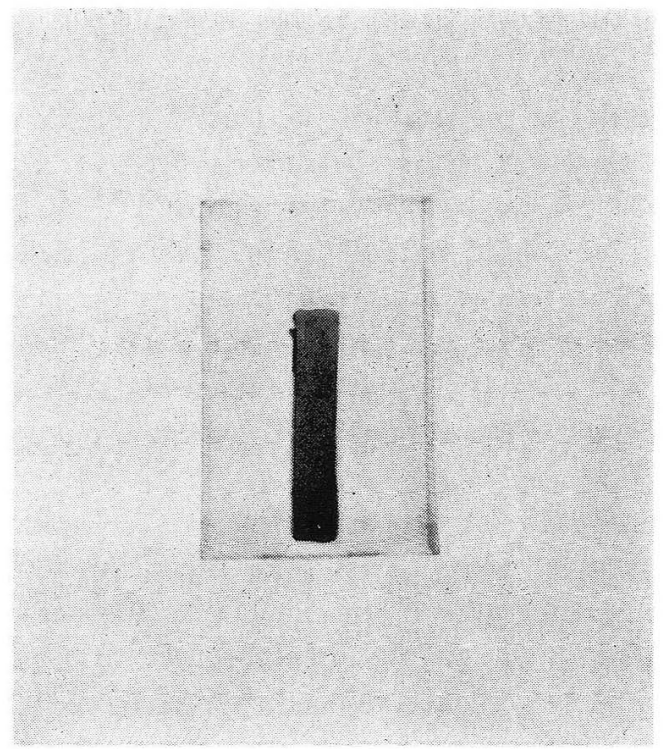

Figure 4 Section of specimen used for Vicker's hardness test

For tensile strength and elongation tests, a universal testing machine, "AUTO GRAPH" Type DSS-2000*, was used with a crosshead speed of $10 \mathrm{~mm} / \mathrm{min}$. Vicker's hardness was measured at many points from the surface to the interior on sections of specimens embedded in acrylic resin as shown in Figure 4.

The surface characteristics of castings of plate-type specinens were observed after pickling. Surface roughness was measured by a roughness meter, "SURFCOM" Type $300 \mathrm{~B}^{* *}$.

\section{RESULTS AND DISCUSSION}

(1) Particle size distribution

Particle sizes were divided into four classes and the results are seen in Table 3 . As

Table 3 Particle size distribution of mold materials

\begin{tabular}{|c|c|c|c|c|c|}
\hline \multicolumn{2}{|c|}{ Types of mold materials } & $\begin{array}{l}<200 \text { mesh } \\
(<74 \mu \mathrm{m})\end{array}$ & $\begin{array}{l}100 \sim 200 \text { mesh } \\
(74 \sim 149 \mu \mathrm{m})\end{array}$ & $\begin{array}{l}50 \sim 100 \text { mesh } \\
(149 \sim 297 \mu \mathrm{m})\end{array}$ & $\begin{array}{l}>50 \mathrm{mseh} \\
(>297 \mu \mathrm{m})\end{array}$ \\
\hline \multicolumn{2}{|c|}{$\begin{array}{l}\text { Phosphate-bonded silica } \\
\text { investment }\end{array}$} & $81.5 \%$ & $17.5 \%$ & $1.0 \%$ & - \\
\hline \multirow{2}{*}{$\begin{array}{l}\text { Magnesia } \\
\text { Cement }\end{array}$} & $\begin{array}{l}\text { after } \\
\text { pulverizing }\end{array}$ & 97 & 3 & - & - \\
\hline & $\begin{array}{l}\text { before } \\
\text { pulverizing }\end{array}$ & 34.7 & 18.6 & 24.2 & 22.0 \\
\hline
\end{tabular}

* Manufacturer: SHIMADZU SEISAKUSHO LTD., Kyoto, Japan

** Manufacturer: TOKYO SEIMITSU CO., LTD., Tokyo, Japan 
$81.5 \%$ of phosphate investment passed through a 200 mesh sieve, the powder of this investment was considerably small. As for the magnesia cement, although almost all powder which had been pulverized passed through a 200 -mesh sieve, only $34.7 \%$ of the powder passed through it before pulverization. Therefore, the coarsest powder was magnesia before pulverization and it was also the finest one after being pulverized.

(2) Compressive strength

The compressive strength of mold materials was measured before and after firing at $800^{\circ} \mathrm{C}$. The strength of the magnesia cement was measured only using the coarse materials. As seen in Figure 5, the strength of the phosphate investment was remarkably decreased due to firing; on the other hand, the strength of the magnesia cement was considerably increased. Thus, the strength of the magnesia investment was higher than that of the phosphate after firing.

(3) Thermal expansion rate

Thermal expansion rates were measured for phosphate-bonded silica and coarsepowdered magnesia investments. As shown in Figure 6, the thermal expansion curve of the magnesia investment was nearly linear, whereas that of the phosphate-bonded silica investment rose sharply at temperatures of about $300^{\circ} \mathrm{C}$ and $600^{\circ} \mathrm{C}$ due to the presence of cristobalite and quartz, respectively. At a casting temperature of $800^{\circ} \mathrm{C}$, the thermal expansion rate of the magnesia investment was somewhat smaller than that of the phosphatebonded investment.

The lower expansion rate of magnesia investment gave us some concern about the dimensional accuracy of the castings. According to a practical fitness test, however, this problem seemed to be solved by enlarging the model with a spacer attached to its surface. Further investigation are being carrind out on the fitness of the castings.

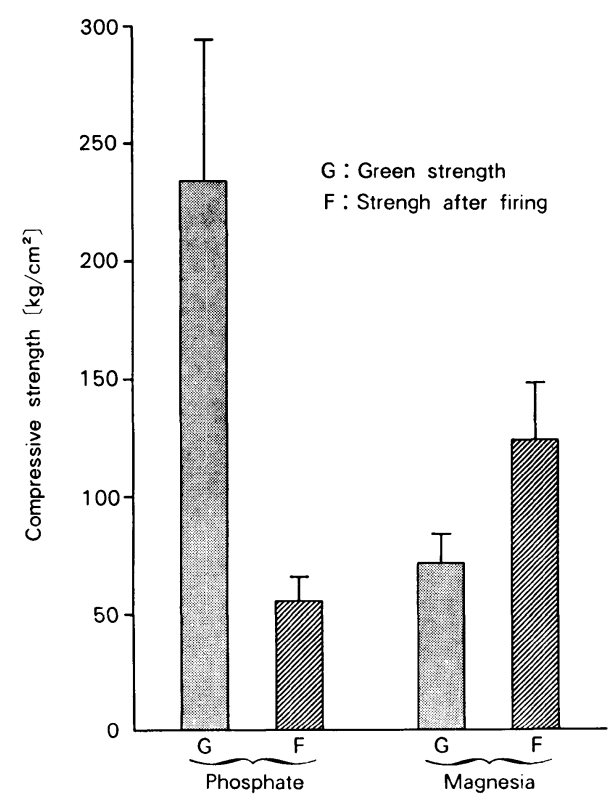

Figure 5 Compressive strength of mold materials 


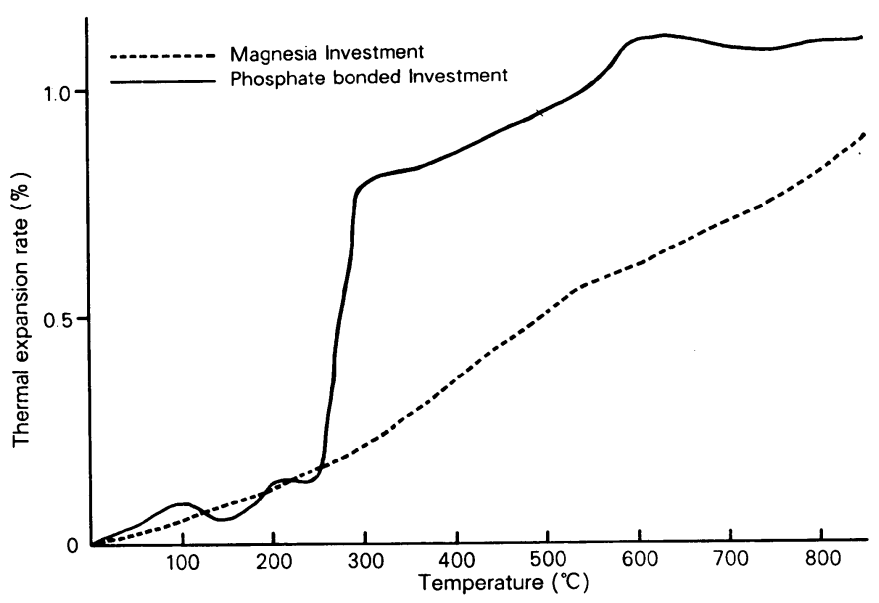

Figure 6 Thermal expansion curves of investments

Table 4 Mechanical properties of pure titanium and binary or ternary titanium-based alloys (cast with phosphate-bonded investment)

\begin{tabular}{l|l|c|c|c}
\hline \multicolumn{1}{c|}{ System } & Composition & $\begin{array}{c}\text { Vicker's hardness } \\
\text { number }\end{array}$ & $\begin{array}{c}\text { Tensile strength } \\
\left(\mathrm{kg} / \mathrm{mm}^{2}\right)\end{array}$ & $\begin{array}{c}\text { Elongation } \\
(\%)\end{array}$ \\
\hline $\mathrm{Ti}$ & $99.7 \mathrm{Ti}$ & 210 & 51.8 & 1.5 \\
$\mathrm{Ti}-\mathrm{Ni}$ & $80 \mathrm{Ti}-20 \mathrm{Ni}$ & 318 & 41.4 & 0 \\
$\mathrm{Ti}-\mathrm{Cu}$ & $70 \mathrm{Ti}-30 \mathrm{Cu}$ & 364 & 16.6 & 1.9 \\
$\mathrm{Ti}-\mathrm{Co}$ & $80 \mathrm{Ti}-20 \mathrm{Co}$ & 474 & 46.3 & 1.4 \\
$\mathrm{Ti}-\mathrm{Cr}$ & 80Ti-20Cr & 421 & 36.7 & 0 \\
$\mathrm{Ti}-\mathrm{Ni}-\mathrm{Cu}$ & 80Ti-10Ni-10Cu & 346 & 50.9 & 0 \\
& 60Ti-20Ni-20Cu & 364 & 15 & 0 \\
& 40Ti-30Ni-30Cu & 253 & 35 & 1.3 \\
\hline
\end{tabular}

(4) Mechanical properties

The mechanical properties of pure titanium and about three hundred binary or ternary titanium-based alloys cast into phosphate-bonded investments were measured. However, most of these alloys were so brittle or hard that they were unsuitable as dental alloys.

Some alloys having comparatively good properties are shown in Table 4 . Even these alloys seemed to be too hard and too small in elongation for dental use. Therefore, it was found that pure titanium or titanium-based alloys should not be cast in conventional phosphate-bonded silica investments because the interaction between titanium and the main component of the mold, viz. silica, made the titanium castings hard and brittle.

A second investigation on the mechanical properties of alloys were carried out using various mold temperatures with phosphate-bonded investment with or without magnesia coating and magnesia investments with coating. As casting metals, commercial pure titanium and the 6Al-4V-titanium-based alloy were used.

It is noted in Figure 7 that the tensile strength of pure titanium was not so different due 


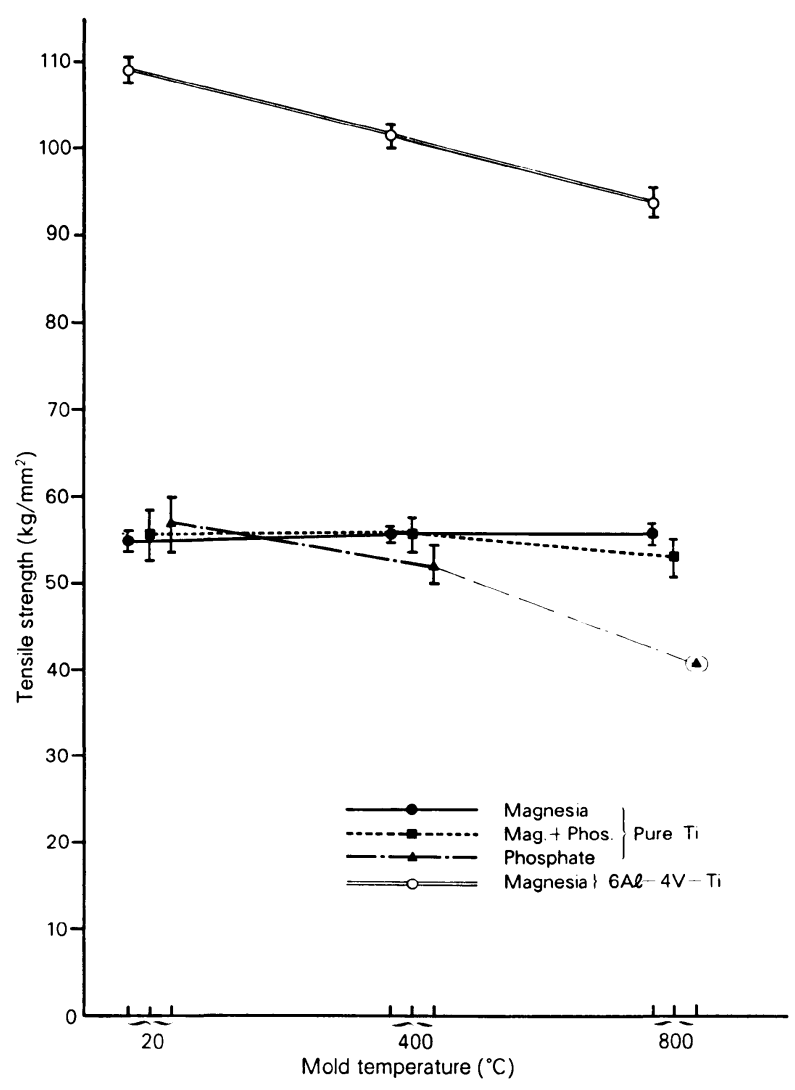

Figure 7 Tensile strength of pure titanium and a $6 \mathrm{Al}-4 \mathrm{~V}-\mathrm{Ti}$ alloy

to the types of mold materials, while the elongation values in the case of magnesia investments were superior to those when phosphate-bonded investments were used (Figure 8). In case of the combination of magnesia coating and phosphate investing, intermediate values were obtained. With respect to the influence of mold temperature, the elongation values were not so affected in the case of the magnesia investment, while they were significantly influenced in the case of the combination of magnesia coating and phosphate investing. When the phosphate-bonded mold without magnesia coating was used at $800^{\circ} \mathrm{C}$, the casting was almost impossible due to the reaction between titanium and mold materials.

Vicker's hardness at the surface layer was higher than in the inner part as shown in Figure 9. This is because of the oxidation at the surface of titanium castings. However, the increasing rate of hardness at the surface layer is smaller with magnesia investments than with phosphate-bonded ones.

In the case of the $6 \mathrm{Al}-4 \mathrm{~V}$-titanium alloy, only magnesia investments were used as the mold material. The tensile strength and Vicker's hardness of this alloy were considerably higher and the elongation was considerably lower than pure titanium as shown in Figures 7, 9 and 8, respectively

As for the $13 \mathrm{Cu}-\mathrm{Ti}$ alloy, which was made in the United States, castings were made at 
a mold temperature of $800^{\circ} \mathrm{C}$ only. The mechanical properties of castings of this alloy are shown in Table 5. Its tensile strength and hardness were higher than those of pure titanium, whereas its elongation was much lower than that of pure titanium. Since the fusing temper-

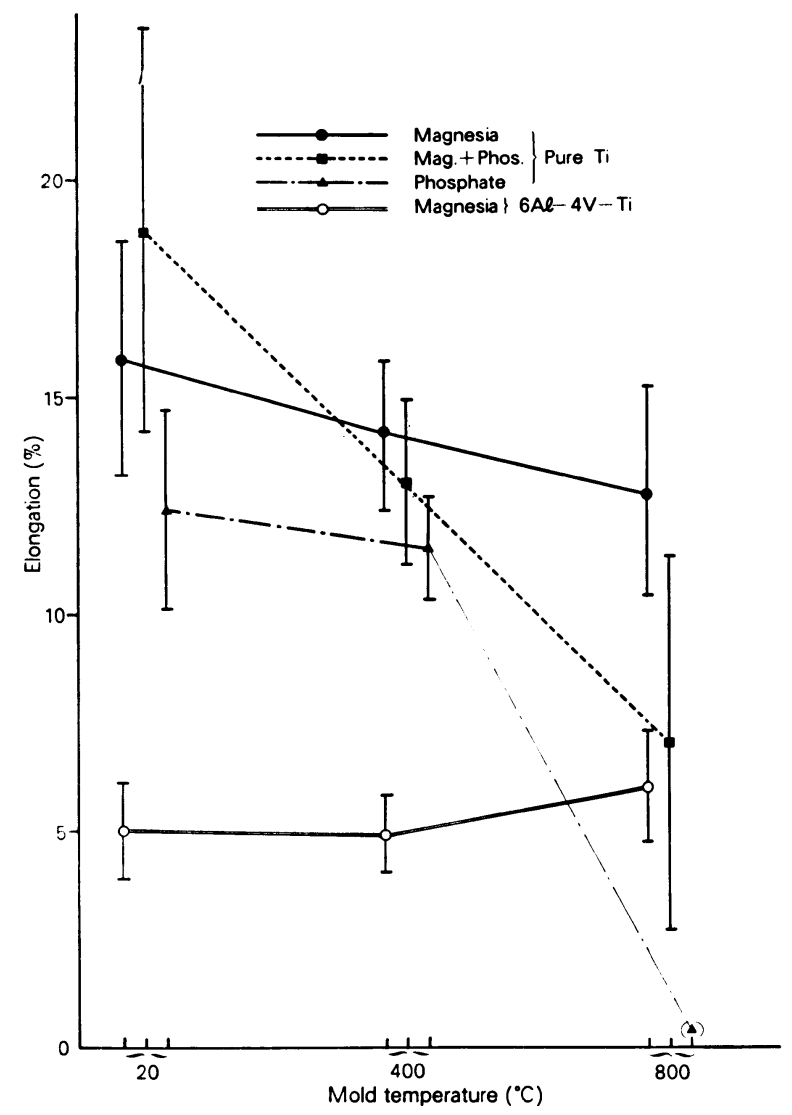

Figure 8 Elongation of pure titanium and a $6 \mathrm{Al}-4 \mathrm{~V}-\mathrm{Ti}$ alloy

Table 5 Comparison of mechanical properties of a $13 \mathrm{Cu}-\mathrm{Ti}$ alloy and pure titanium

\begin{tabular}{l|c|c|c|c}
\hline \multicolumn{1}{c|}{ Metals } & Mold materials ${ }^{+}$ & $\begin{array}{c}\text { Tensile strength } \\
\left(\mathrm{kg} / \mathrm{cm}^{2}\right)\end{array}$ & $\begin{array}{c}\text { Vicker's hardness } \\
\text { numbert }(\mathrm{Hv})\end{array}$ & $\begin{array}{c}\text { Elongation } \\
(\%)\end{array}$ \\
\hline $\begin{array}{l}\text { 87Ti-13Cu } \\
\text { alloy }\end{array}$ & $\begin{array}{l}\text { Phosphate-bonded } \\
\text { silica investment* }\end{array}$ & $60.0(3.8)^{* *}$ & $492(8.7)$ & $1.1(0.4)$ \\
\cline { 2 - 5 } & Magnesia cement & $65.6(10.0)$ & $362(4.7)$ & $1.7(0.9)$ \\
\hline Pure Ti & Magnesia cement & $52.6(2.9)$ & $272(58.9)$ & $9.4(3.6)$ \\
\hline
\end{tabular}

*Phosphate-bonded investment (WASHI-Vest) was used without magnesia coating.

**Parentheses enclose standard deviations. Numbers of specimens were five or six.

tMold temperature was $800^{\circ} \mathrm{C}$ in all cases.

$\dagger+$ Vicker's hardness was measured at the surface of the castings. 


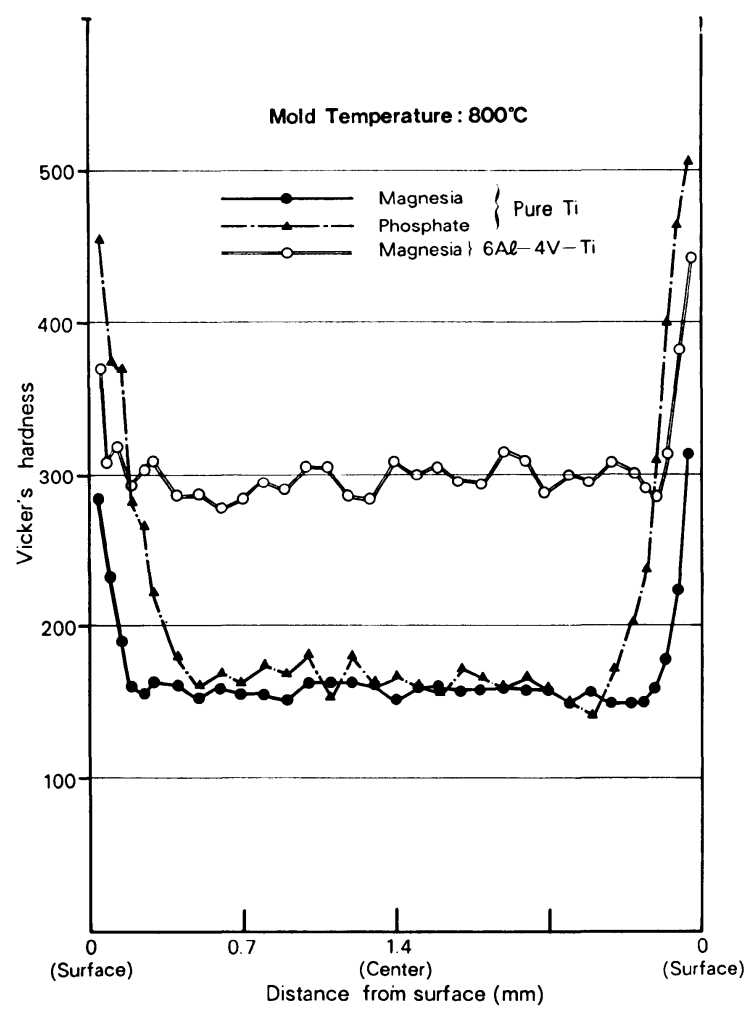

Figure 9 Vicker's hardness of pure titanium and a $6 \mathrm{Al}-4 \mathrm{~V}-\mathrm{Ti}$ alloy

ature of this alloy is presumed to be fairly low, viz. about $1400^{\circ} \mathrm{C}$, it was able to be cast into the mold of the phosphate-bonded investment. Although differences in mechanical properties due to mold materials were small, the hardness was higher and the elongation was lower with the phosphate-bonded silica investment. These results indicate that a little hardening of the casting surface had occurred by interaction between alloy and silica investment.

Table 6 gives a comparison of mechanical properties among the castings of pure titanium, titanium alloys, and other dental canting alloys. According to this table, the mechanical properties of pure titanium are close to those of gold alloys, types III or IV, and it is more ductile than $\mathrm{Ni}-\mathrm{Cr}$ or $\mathrm{Co}-\mathrm{Cr}$ alloys. On the other hand, titanium alloys are on the average as strong, hard, and brittle as $\mathrm{Co}-\mathrm{Cr}$ alloys for plates.

Therefore, pure titanium is suitable for crowns and bridges, whereas titanium alloys are too hard for this use. However, when strength and hardness are needed, for example, in the case of appliances for dental implants, titanium alloys may be more suitable than pure titanium.

(5) Surface characteristics of castings

Figure 10 shows the state of the appearance of the surface of pure titanium castings after pickling in hydrochloric acid. The use of the magnesia investment gave a cleaner, 
Table 6 Mechanical properties of titanium alloys and other dental casting alloys

\begin{tabular}{|c|c|c|c|c|}
\hline \multicolumn{2}{|c|}{ Types of alloys } & $\begin{array}{l}\text { Tensile strength* } \\
\quad\left(\mathrm{kg} / \mathrm{mm}^{2}\right)\end{array}$ & $\begin{array}{l}\text { Vicker's hardness } \\
\text { number* }(\mathrm{Hv})\end{array}$ & $\begin{array}{l}\text { Elongation* } \\
\qquad(\%)\end{array}$ \\
\hline \multirow{6}{*}{ Gold alloys** } & Type I & 27 & 72 & 30 \\
\hline & Type II & 30 & 89 & 25 \\
\hline & Type III softened & 35 & 110 & 20 \\
\hline & hardened & 41 & 121 & 12 \\
\hline & Type IV softened & 50 & 147 & 20 \\
\hline & hardened & 75 & 237 & 4 \\
\hline \multirow{3}{*}{\multicolumn{2}{|c|}{$\begin{array}{l}\text { Nickel-Chromium alloys }{ }^{\dagger} \text { for }\left(\begin{array}{l}\text { crown, bridge } \\
\text { fused porcelain }\end{array}\right. \\
\text { Cobalt-Chromium alloys }{ }^{\dagger} \text { for plate }\end{array}$}} & 53 & 200 & 7 \\
\hline & & 74 & 277 & 5 \\
\hline & & 75 & 380 & 3 \\
\hline \multicolumn{2}{|c|}{ Pure titanium ${ }^{\dagger} \dagger$} & 55 & 210 & 13 \\
\hline \multirow{2}{*}{\multicolumn{2}{|c|}{ Titanium-based alloys ${ }^{\dagger}\left\{\begin{array}{l}6 \mathrm{Al}-4 \mathrm{~V}-\mathrm{T} \\
13 \mathrm{Cu}-\mathrm{Ti}\end{array}\right.$}} & 93 & 320 & 5 \\
\hline & & 66 & 362 & 1.7 \\
\hline
\end{tabular}

*Only mean values are described.

**Values for the gold alloys are quoted from the literature (10). Units have been changed from $\mathrm{MN} / \mathrm{m}^{2}$ to $\mathrm{kg} / \mathrm{cm}^{2}$ and from $\mathrm{H}_{\mathrm{B}}$ to $\mathrm{H}_{\mathrm{v}}$.

$\uparrow$ Values for nickel-chromium or cobalt-chromium alloys are quoted from the Japanese literature.

$\dagger \dagger$ Values for pure titanium and titanium alloys are those obtained in this study with the mold material being magnesia cement at the mold temperature of $800^{\circ} \mathrm{C}$.

\begin{tabular}{|c|r|r|r|}
\hline Materials & $20^{\circ} \mathrm{C}(\mathrm{RT})$ & $400 \mathrm{C}$ & $800^{\circ} \mathrm{C}$ \\
\hline Magnesta & & & \\
\hline Mag Phos & & & \\
\hline Phosphate & & & \\
\hline
\end{tabular}

Figure 10 Appearance of castings of pure titanium after pickling

white surface than when the other two types of investments were used. Higher mold temperatures made the surface turn black.

The average values of roughness under different investment conditions can be found in Figure 11, and Figure 12 shows some examples of typical roughness curves. From these data it can be concluded that the surface roughness was least for the magnesia investment. (6) Some examples of titanium castings

Figure 13 shows some types of blades used for dental implants, which were made with magnesia investments. Even though they are in the state after sandblasting but before polishing, the casting surfaces are quite smooth and clean. In the case of blades for implants, 


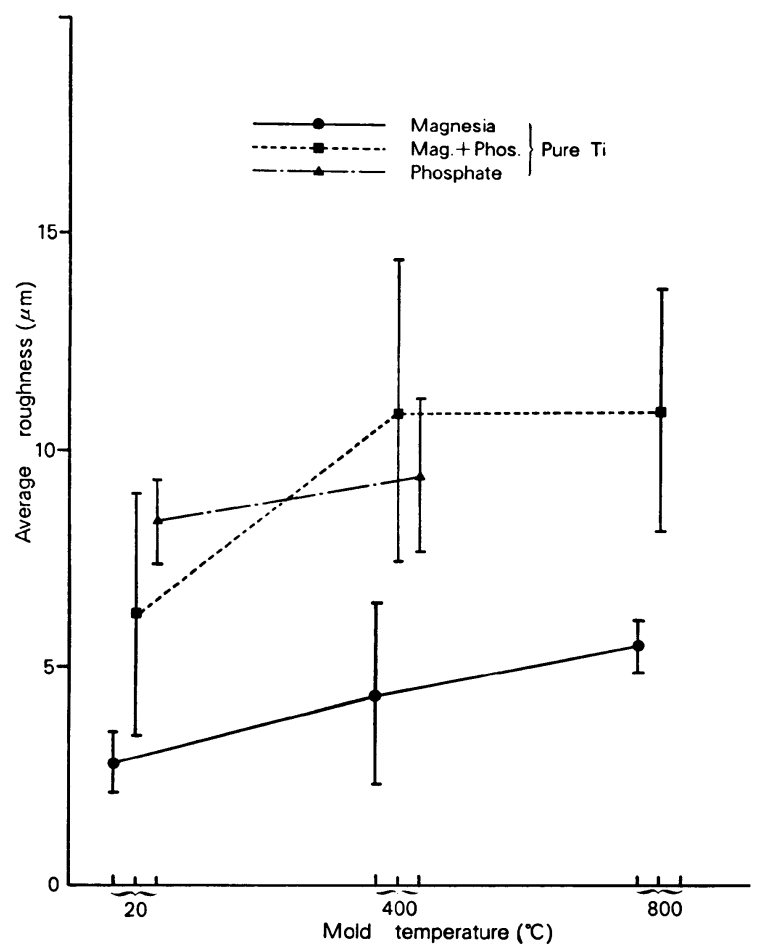

Figure 11 Average surface roughness of pure titanium castings

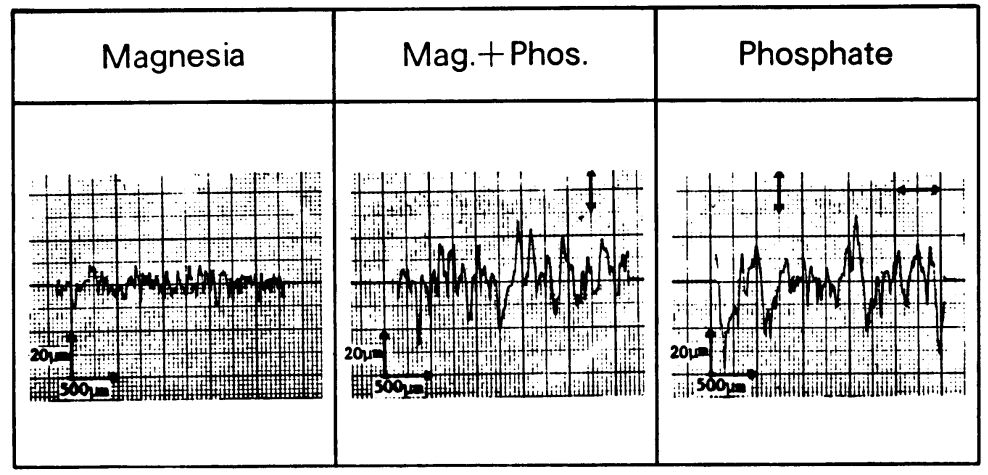

Figure 12 Surface roughness curves of pure titanium castings

strict dimensional accuracy is not necessary.

Examples of a crown and bridge made with magnesia investments are shown in Figure 14. They have already been pickled in hydrochloric acid. The surface states are fairly smooth for both crown and bridge even without polishing.

These pure titanium castings of implant blades, crowns, and bridges could be made easily with the new type of casting machine and a new mold material, magnesia. This casting procedure seems to be a promising way to utilize pure titanium or titanium alloys as casting metals in the dental field. 


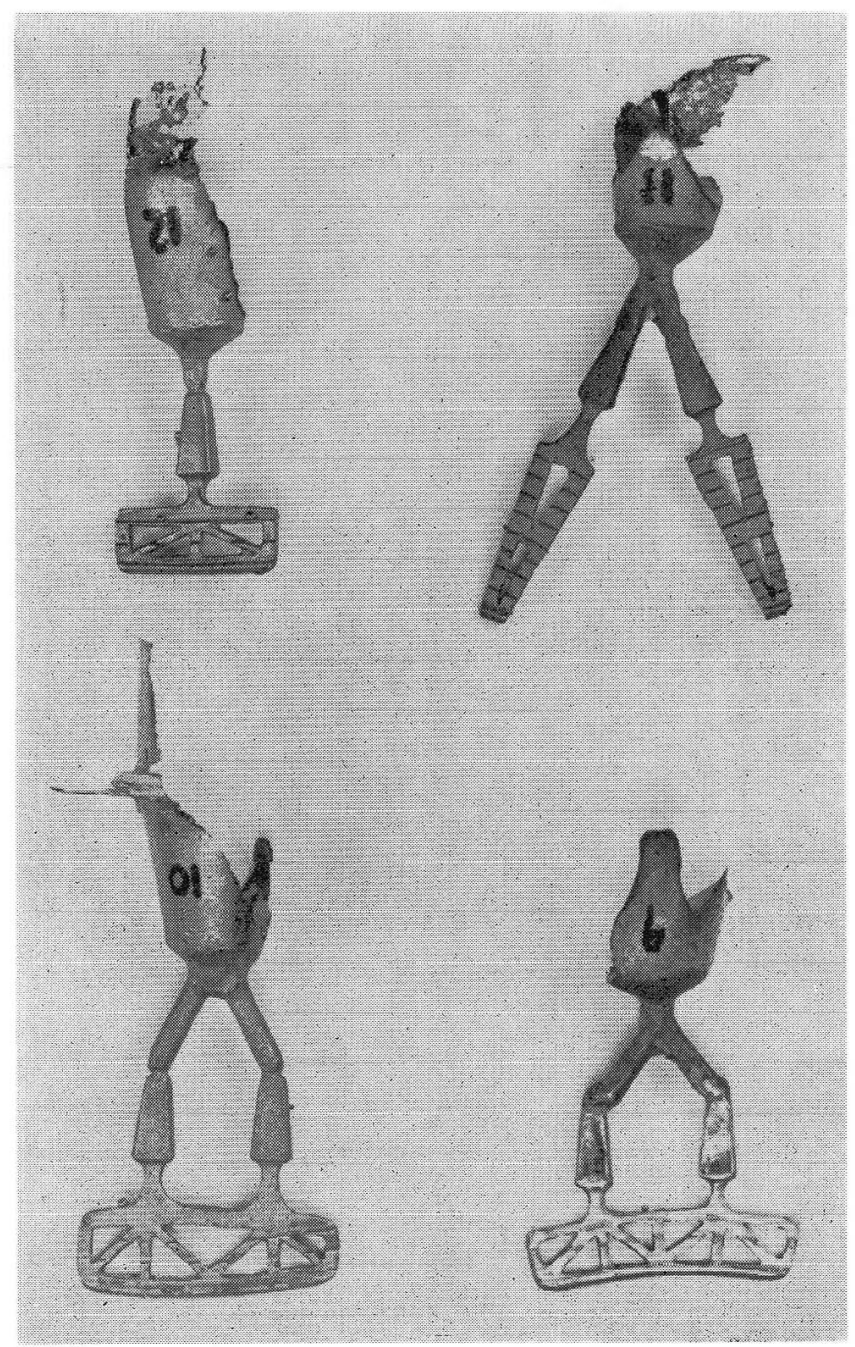

Figure. 13 Titanium castings made with magnesia investment (1) -Blades for dental implants-

\section{CONCLUSIONS}

Pure titanium and titanium-based alloys could be cast with the new dental casting machine, "CASTMATIC". The results obtained were as follows:

(1) The magnesia investment was much more suitable for casting of titanium than the phosphate-bonded silica investment.

(2) The use of magnesia as a coating material combined with phosphate-bonded silica investment had a little effect on the properties of titanium castings.

(3) The thermal expansion rate of magnesia investments at $800^{\circ} \mathrm{C}$ was not so different from that of phosphate-bonded investments. However, further investigation is necessary as to the accuracy of the castings. 


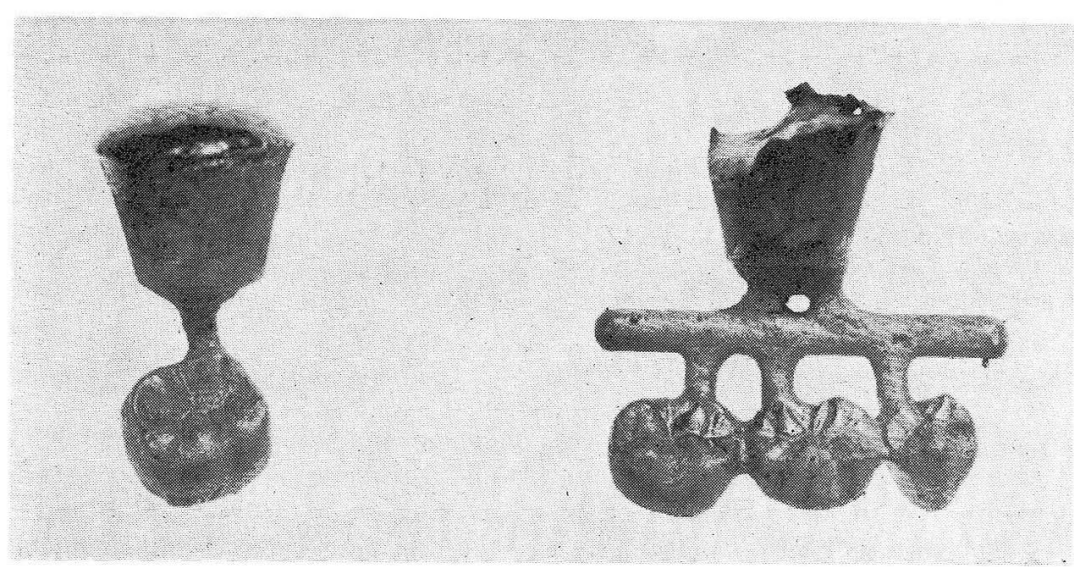

Figure 14 Titanium castings made with magnesia investment (2) - Crown and Bridge-

(4) Pure titanium and titanium alloys seemed to be suitable for crowns or bridge and prostheses for dental implants, respectively, with regards to their mechanical properties.

(5) Practical castings of titanium such as crowns, bridges, and blades for dental implants were able to be made successfully using magnesia investments.

\section{REFERENCES}

1) $\mathrm{DD}$, Council on Dental Materials: Biological effects of nickel-containing dental alloys, JADA, 104: 501-505, 1982.

2) Waterstrat, R.M., Rupp, N.W. and Franklin, O.: Production of a cast titanium-base partial denture, J. Dent. Res., 57: 254, 1978.

3) Ida, K., Takeuchi, M., Togaya, T. and Tsutsumi, S.: Studies on the dental casting of titanium alloy (Part I, Casting of pure titanium), J. Jap. Res. Soc. Dent. Mat. Appl., 37: 45-52, 1980, (in Japanese).

4) Ida, K., Takeuchi, M., Togaya, T., Tsutsumi, S., Ikeda, K. and Murayama, K.: Studies on dental casting of titanium alloy (Part II, Propertics of titanium-nickel alloys), J. Jap. Res. Soc. Dent. Mat. Appl., 37: 145-153, 1980, (in Japanese).

5) Ida, K., Togaya, T., Takeuchi, M., Tsutsumi, S., Ikeda, K. and Murayama, K.: Studies on dental casting of titanium alloy (Part III, Properties of binary or ternary alloys containing titanium), J. Jap. Res. Soc. Dent. Mat. Appl., 37: 297-300, 1980, (in Japanese).

6) Togaya, T., Yabugami, M. and Ida, K.: Studies on dental casting of titanium alloy (Part IV, Casting of pure titanium and titanium alloys with magnesia investment), J. Jap. Res. Soc. Dent. Mat. Appl., 38: 460-467, 1981, (in Japanese).

7) Togaya, T., Yabugami, M. and Ida, K.: Studies on dental casting of titanium alloy (Part V, In case of zircon sand mold and magnesia coating), J. Jap. Res. Soc. Dent. Mat. Appl., 38: 658-662, 1981, (in Japanese).

8) Ida, K., Tsutsumi, S. and Togaya, T.: Titanium or titanium alloys for dental casting, J. Dent. Res., 59: $985,1980$.

9) Ida, K., Togaya, T., Tsutsumi, S. and Y. Tani,: Casting of pure titanium or titanium alloys with magnesia investment, J. Dent. Res., 61: 246, 1982.

10) Craig, R.G. and Peyton, F.A.: Restorative dental materials, 5th ed., The C.V. Mosby Co., 1975, p. 315. 


\title{
本号掲載論文の和文抄録
}

\author{
Cupt の規則化に及ぼす冷却速度の影響 \\ 久恒邦博*, 太田道雄, 山根正次 \\ 九州大学歯学部歯科理工学講座 \\ *現在 : 長崎大学歯学部歯科理工学講座
}

等原子比合金 $\mathrm{CuPt}$ の規則化について, 臨界温度以上 $\left(900^{\circ} \mathrm{C}\right)$ から室温まで種々の速度で冷却した場合の影響 を電気抵抗測定, 硬さ試験, X線回折, 透過型電子顕微 鏡により検討した。水中冷却した武料は完全な不規則相 （f $\mathrm{fc}_{\mathbf{c c}}$ )であったが, 空冷した試料は冷却中にかなりの則

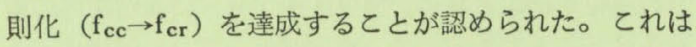

過剩空孔の消費に伴なう規則化である。冷却速度が遅く なるにつれて規則度は上昇し， $-25^{\circ} \mathrm{C} / \mathrm{min}$ 以下におい ては完全な規則状態が得られた。規則化による硬化の寄 与は中間の泠却速度である空冷武料でピークが認められ た。この硬さピークに対応する規則化は粒内におけるマ イクロドメインの形成に起因する均一反応であった。

マグネンア系埋没材による純チタンおよびチタン合金の歯科鋳造について

井田一夫*, 都賀谷紀宏*, 堤 定美*, 竹内正敏*

*京都大学医用高分子研究センター歯科材料応用研究部門

純チタンおよびチタンを主成分とする合金は，耐食性 や生体適合性が非常によいとと, 軽いとと,などの特徽 を有するので，歯科におけるクラウン・ブリッジ用，床 用，インプラント用などの材料として興味のある金属で ある。

しかし，融点が高いととや高温における反応性が大き いとと,などのために鋳造が極めて困難であり，てれま で歯科用金属として使用されていなかった。

本研究は, 新しい鋳造機 “CASTMATIC” を使用し, マグネシアを主成分とする埋没材を使用して純チタンお
よびチタン合金を鋳造し，鋳造物の機械的性質，表面性 状などを検討したものである。またマグネシア系埋没材 の物理的性質も検討した。

実験の結果，この方法で鋳造した純チタンは金合金 （硬質）に近い機械的性質を示し, 鋳肌のよいものが得 られた。またインプラント用ブレード, クラウン, ブ リッジなど臨床用のパターンにおいてあ外観のきれいな 鋳造体を得ることができた。しかし寸法精度については 更に検討が必要である。

\section{コンポシットレンジの marginal fracture toughness について}

谷 嘉明

京都大学医用高分子研究センター 歯科材料応用研究部門

歯科用修復材の縁端強度は臨床的に重要な性質である あのの，その測定法は確立されていない。本報では，粉 末治金工業の分野で，圧粉体の成形性を測定する規格試 験法として用いられている Rattler 陚験法を応用して, 各種コンポジットレジンの marginal fracture toughness を評価した。各材料について, $6 \times 6 \times 3 \mathrm{~mm}$ の角片 5 個 づつ作製し, Rattler 試験機の青銅金龬製シリンダー
ケージの中に入れ， 87 r.p.m の回転速度で 10,000回転さ せて, 試片の縁端部を磨滅させた。試験前の試片重量に 対する試験後の重量損失率を求めた。重量損失率の小さ いものほど marginal fracture toughness にすぐれてい ることになる。

実験の結果，MFR があっとあすぐれ，次いで日歯用 コンポジットレジンで, 従来型コンポジットレジンが 